the metropolitan hospitals. If he refers to my letter, he will find that. I assume nothing, but state the fact that these hospituls bave the highest mortality. He next states that the nursing at St. Thomas's is not conducted on the Night. ingale plan ("systern" would, perhaps, have been a better word); but, as be also professes ignorance of what that system is, it would be advisable for him to study Miss Nightingale's most excellent work on the subject before venturing on a statement on a matter upon which be is apparently ill-informed. Again, he makes it appear that I think that good nursing in hospitals tends to raise their mortality, whereas I rather inferred that bad nursing raised, while gnod nursing lowered, the death-rate.

Dr. Bristowe and Dr. Greenfield both agree that the exceptionally high denth-rate at St. Thomas's can be accounted for by the small size of the hospital. It almost makes one smile to find that a hospital with 576 beds, 400 of which are in constant use, in termed small, and placed in the same category as regards siz? with hospitals with 172 and 154 beds respectively. "Statistics are," as Dr. Bristowe says, "wonderful things, and prove a great deal, hut I think that most people will require more proof than he adduces to convince them " that the high deach-rate at St. Thomas's is due to the small number of beds which the staff have at their disposal. If it be true the death-rate ought to vary inversely as the size, why should University College, with 154 beds, have a mortality of only $11 \cdot 46$, while St. Thomas's with 400 reaches to 11.73 ? My explanation of the high mortality may be wrong, very probably it is, but it is not so palpably absurd as that adopted by Dr. Bristowe. Perbaps on further consideration he will be able to discover some other cause for a state of things which I still consider eminently unsatisfactory.

I am, Sir, your obedient servant,

Park-square, Leeds, August 11th, 1877.

A. F. MaGirs.

\section{ON THE CONNEXION BETWEEN MEASLES AND ROTHELN.}

To the Editor of THN LANCET.

Srr,-My friend, Dr: Sharkey, published in your columns a few weeks since, a striking case which occurred in my practice, showing the non-identity of chicken-pox and small-pox. Dr. Farquharson, whose paper, read before the Clinical Society, induced. Dr. Sharkey to write to you, acknowledged in your issue of the 21st ult. the importance of Dr. Sharkey's case in reference to the question then under dispute, but incidentally maintains in his letter that there is a similar identity between roseola, or spurions measles or xötheln, and tro measles, to that which be still reems inclined to think exists between varicella and smallpox.

I freely acknowledge the very great resemblance there is between measles and rotheln, and that $I$ would by no means undertake in every instance to distinguish a case of the one disease from a case of the other; but close resemblance does not necessarily imply identity, and, for my own part, having seen a great deal of both diseases, I have no hesitation in ranging myself with those who maintain their absolute distinctness from one another, and, in confirmation of my opinion, beg leave to lay before your readers the following two narratives:-

(1) A little more than nine years ago, all my children then born, geven in number, had measles, which was introduced among them by my eldest boy, who had contracted it at a public school to which I was physician, and where I had therefore full opportunity of observing the course of the epidemic. Four years ago this summer, while at the seaside, my eldest two daughters were attacked, within a week of one another, with what I regarded as rötheln in a well-marked form. It did not spread from them to any other of my children, although at that time two others had been added to their number, and these two had never had measles. About fifteen months ago, one of the two children who had not hitherto had measles, and who bad been exposed to the contagion of rätheln, were brought into relation with the poison of measles and contracted the disease.

(2) Three years ago last Christmas, five of the children of a mear relative of mine had measles in a characteristic form. In the following March, the resideut guvern $r$ ss, who had been exposed to the contagion of measles at C'bristmas, but had not become affected by it, had a well.malked attack of rötheln, and a week or ten days afterwards one of the children, who had had measles three months previously, had also an attack of xotbeln. The disease did not extend. I attended the family on both occasions.

These narratives seem to show two things-namely: 1st, that rötheln and measles are not mutually protective, as they should be if they were mere modificati ns of the same disease; and, 2nd, that 1 ötbeln is not nearly 80 contagious as measles. I may add that $I$ have witnessed many other outbreaks of $r o ̈$ theln besides the above, and that the distribution of the disease has, as far as $I$ could learn, in no case been influenced by the previous occurrence of measles.

It seems to me that the grounds for maintaining the nonidentity of measles and rötheln and of small-pox and chickenpox, respectively, are quite as strong as thise on which we maintain the non-identity of measles avd scarlet fever, which were confounded with one another by the physicians of the last century; or as those on which we aszert the non-identity of typhus and enteric fever-distases which Dr. Stokes still contends to be one and the same The mere fact that sporadic cases of one infectious dispase are met with during the epidemic prevalence of another infectious disease is no more a pronf of their common origin, than the fact of patches of oats or barley being discovered in a field of wheat is a proof that those cerrals all spring from the same seed. Dr. Farquarson must ther fore forgive me if I put another interpretation than his upon the tatement made in his letter, that " roseola, or spurious measles, will reproduce itself in its own kind fifty or sixty times; and the sixty-first may, as I have seen, turn out to be a true case of the major disease."

I am, Sir, your obedient servant,

Old Burlington-street, August 11th, 1877. J. S. BRistowh.

\section{"A POCKET INSULATFD SURFACE THERMOMETER."}

To the Editor of THE LaNCET.

SrR,-Allow me to state in your columns that the surface thermometer, described in THe LANCET of Angust 11th, is, in its essential feature-i.e., the spiral bulb partly surrounded by a metallic cup-identical with the surface thermometer devised by myself some six years ayn, and since then frequently used by me in the wards of the Westminster Hospital.

The thermometer has also been manufactured and sold by Mr. T. Hawksley, 300, Oxford street, for several years past. It has been exhibited by him at the last of the annual International Exhibitions held at South Kensingtrn, at the exhibition of scientific instruments at the same place last summer, and on various other occasions.

On applying this thermometer to surfaces of known temperature within the range of temperature of the human body, I found that, after five minutes' contact, the temperature indicated by the thermometer is, within from a quarter to one-fifth of a degree Fahrenheit, the correct temperaturo of the surface.

Westminster Hospital, August 21st, 1877. Yours, \&c.

We have communicated with Dr. Mortimer Grauville, and the following is his reply :-

\section{To the Editor of Tru LanceT.}

SrR,-I am obliged for the private communication with respect to Dr. Dupré's letter which is to appear in THr LANCET this week, and for the eight of his instrument.

It is obvious that Dr. Dupré has anticipated me in the adoption of the principle common to both instruments. The great feature in which mine differs from his-and this, I think, makes all the difference between a " pocket" thermometer and one which can scarcely be so designated-is that I have'suspended the glass tube by an india-rubber washer, and arranged the register horizontally, so that the apparatus packs in a very small compass. The ordinary difficulties attending the nee of a horizontal scale have been surmounted, and the makers guarantee the perfoot acearacy 